\title{
Implications of climate change for macrophytic rafts and their hitchhikers
}

\author{
Peter I. Macreadie ${ }^{1, *}$, Melanie J. Bishop ${ }^{2}$, David J. Booth ${ }^{1}$ \\ ${ }^{1}$ School of the Environment, University of Technology, Sydney, New South Wales 2007, Australia \\ ${ }^{2}$ Department of Biological Sciences, Macquarie University, North Ryde, New South Wales 2109, Australia
}

\begin{abstract}
Most models predicting changes to species distributions under future climate scenarios ignore dispersal processes, despite their importance in determining community structure in both terrestrial and aquatic systems ('supply-side ecology'). In the marine environment, facilitation of long-distance dispersal of coastal organisms by macrophytic rafts may be severely modified by climate impacts on raft supply, quality, and persistence, and on transport processes. Increasing storminess in the coastal zone, higher water temperatures, and changes in water circulation represent some of the key mechanisms that will directly affect rafts, while increases in herbivore metabolism due to higher water temperatures are likely to indirectly reduce raft longevity through raft consumption. Accurate predictions of climate impacts on coastal biodiversity will be contingent on resolution of factors influencing rafting so that this and other dispersal mechanisms can be incorporated into species distribution models.
\end{abstract}

KEY WORDS: Rafting $\cdot$ Drifting $\cdot$ Climate change $\cdot$ Dispersal $\cdot$ Connectivity $\cdot$ Range $\cdot$ Macroalgae $\cdot$ Seagrass Resale or republication not permitted without written consent of the publisher

\section{INTRODUCTION}

One of the key challenges facing ecologists is the prediction of climate change impacts on biological systems, so that appropriate adaptation strategies for conserving biodiversity and its important ecosystem functions may be implemented. Early studies used climate envelope modeling to predict future distributions (Huntley et al. 2004, Thuiller et al. 2005). This approach ignores the important role of biological interactions in influencing distributions and assumes that species' ranges will be able to track shifting climate conditions (Warren et al. 2001). Recently, several excellent studies have redressed the paucity of information on likely effects of climate change on biological interactions (e.g. Matesanz et al. 2009, Maestre et al. 2010, Schweiger et al. 2010). Yet despite the importance of dispersal processes in influencing the distributions of terrestrial and aquatic taxa (e.g. Nathan \& Muller-Landau 2000, Sousa et al. 2007), considerations of how climate change will modify dispersal remain rare (but see Menge et al. 2009).

In the marine environment, rafting - whereby organisms 'hitch a ride' on buoyant material in surface waters-is an important dispersal process that is likely to be impacted by climate change, but that has received little attention. Rafting has been confirmed or inferred based on distributional or genetic evidence for $>1200$ species, comprising diverse taxa (e.g. invertebrates, fish, birds, mammals; Thiel \& Gutow 2005b). Many of the species that raft do not have a pelagic larval stage and are incapable of autonomous dispersal across the ocean (Thiel \& Gutow 2005b). Other rafting organisms do have planktonic larval stages, but are able to disperse larger distances where rafts extend their time in the plankton (e.g. Gillespie et al. in press). 
The floating items that serve as rafts may be of natural or anthropogenic origin, and of abiotic or biotic material (Thiel \& Gutow 2005a). Natural substrata include volcanic pumice, tar balls (from natural seeps), ice, and plant and animal material. Anthropogenic substrata include manufactured wood, tar balls (from oil industry), Styrofoam, and plastics of various sizes, shapes, and surface characteristics. Among natural substrata, macroalgae and seagrasses (hereafter collectively termed macrophytes) and natural wood (i.e. trunks and branches) are the most common and ecologically significant (Hinojosa et al. 2011, Thiel et al. 2011).

Macrophytic rafts begin their journey after detachment from the substratum (Fig. 1 ). This is followed by a period of transport in surface waters by wind and water movement, until eventually they sink, disintegrate, or become cast upon land (Fig. 1). The quality of macrophytic rafts as dispersal vectors is influenced by physical and biological factors that influence their resource provision and longevity (Thiel 2003, Rothäusler et al. 2011a,b). Traits of the macrophytic material influence breeding opportunities for rafting organisms (e.g. Ingólfsson 2000), the availability of food resources for rafting organisms (e.g. Ohta \& Tachihara 2004), and the efficacy of the raft in protecting organisms from predation and abiotically harsh conditions (e.g. Dempster \& Kingsford 2004). Levels of herbivore pressure (Rothäusler \& Thiel 2006, Vandendriessche et al. 2007b, Rothäusler et al. 2011d) and flow conditions (e.g. water temperature

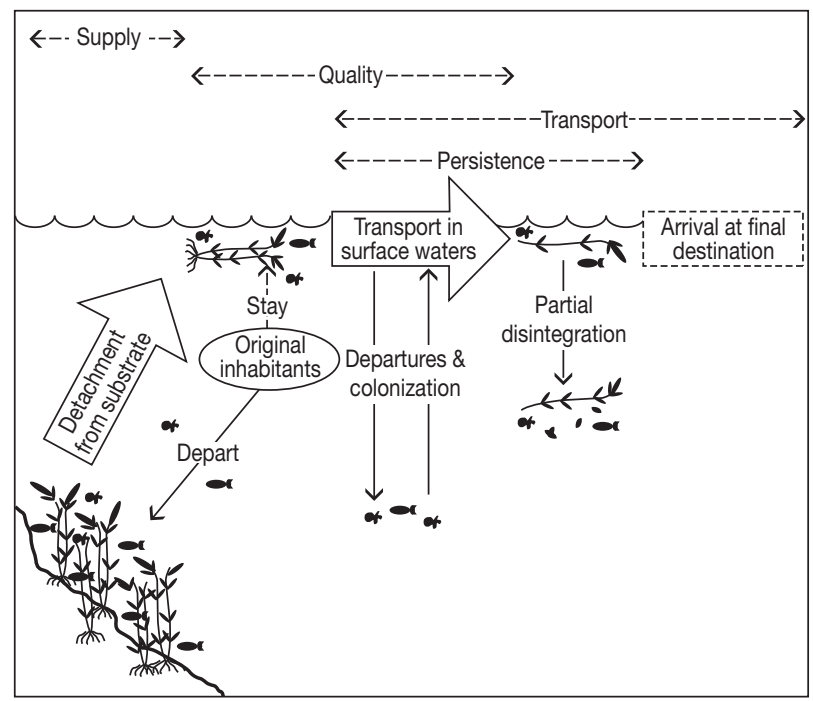

Fig. 1. Conceptual model of the steps involved in rafting facilitating dispersal. Dotted lines span the successional stages of rafting at which changes in the supply, quality, transport, and persistence of rafts will act and ultraviolet radiation; Rothäusler et al. 2011a) influence raft longevity. Thus, relative to other raft materials (e.g. wood, volcanic pumice, plastic macrolitter), macrophytic rafts are highly susceptible to changing climate.

The goal of this 'As We See It' article is to present a series of predictions on how symptoms of climate change (e.g. warming water temperatures, increasingly intense storms, altered circulation patterns, and

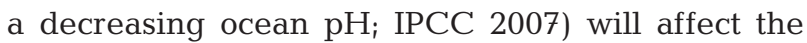
supply, quality, transport, and persistence patterns of macrophytic rafts. We discuss the possible ecological, biogeographical, and evolutionary consequences of such changes for rafting coastal organisms. We conclude with a list of research priorities and provide suggestions for consideration of dispersal processes into species distribution models.

\section{SUPPLY OF RAFT MATERIALS}

The supply of macrophytes for rafting is dependent on the availability of source populations from which the floating substratum can be derived, and the mobilization of material (Fig. 1). Most species that serve as rafts spend their early life history attached to benthic substratum and require detachment from the substratum in order to float (Lüning 1990, Thiel \& Gutow 2005a). In the following paragraphs, we make a case that climate change (IPCC 2007) will increase the rate at which macrophytes detach from benthic substrata by (1) modifying the processes of natural senescence, (2) altering rates of dislodgement by herbivores, and (3) through increases in storm intensity (Table 1 ). We also outline how changes in the productivity and distribution of macrophytes might cascade to their role as rafts.

Many species of seagrass and macroalgae display periods of die-back which coincide with changes in water temperature (e.g. Wetzel \& Penhale 1983, Ang 1985, Kerr \& Strother 1990). During such die-backs, large amounts of macrophytic material are released into the water column (e.g. Kingsford 1992). Recent research has demonstrated that this observation might be explained by rising temperatures reducing tissue life span (Hosokawa et al. 2009). Hence, as coastal oceans continue to warm, enhanced rates of shedding may be seen in some aquatic macrophytes.

Climate change is also anticipated to lead to an increase in the dislodgement of macrophytic material from benthic substrata by herbivores (Table 1). Grazers can weaken the holdfast of algae, causing them to detach from the primary substratum (Tegner et al. 
Table 1. Summary of predicted climate change impacts on plant rafts and their likely consequences for hitchhiking organisms. Up/down arrows represent increase/decrease

\begin{tabular}{|c|c|c|}
\hline $\begin{array}{l}\text { Overall predicted response } \\
\text { of rafts to climate change }\end{array}$ & $\begin{array}{l}\text { Primary climate change driver } \\
\text { and mechanism }\end{array}$ & $\begin{array}{l}\text { Potential consequences for } \\
\text { hitchhikers }\end{array}$ \\
\hline $\begin{array}{l}\uparrow \text { SUPPLY of rafts due to } \\
\text { increases in the rate of } \\
\text { detachment of plants from } \\
\text { benthic substrates, and } \\
\text { increases in the productivity } \\
\text { of fast-growing species under } \\
\text { warmer temperatures }\end{array}$ & $\begin{array}{l}\uparrow \text { Intensity of storms due to accelera- } \\
\text { tion of hydrodynamic forces causing } \\
\text { dislodgement of plants } \\
\uparrow \text { Herbivory of plant stems due to } \\
\text { temperature-induced increases in } \\
\text { grazer metabolism } \\
\uparrow \text { Senescence and leaf shedding due } \\
\text { to temperature-induced die-back }\end{array}$ & $\begin{array}{l}\uparrow \text { Dispersal opportunities due to increases in the } \\
\text { abundance of rafts }\end{array}$ \\
\hline $\begin{array}{l}\downarrow \text { QUALITY of rafts due to } \\
\text { replacement of seagrasses } \\
\text { and kelps with ephemeral } \\
\text { algae in coastal areas }\end{array}$ & $\begin{array}{l}\uparrow \text { Water temperatures favoring faster- } \\
\text { growing, more palatable, short-lived } \\
\text { raft species with smaller average size, } \\
\text { less habitat complexity, and less } \\
\text { resistance to physical breakup } \\
\uparrow \text { Sea levels leading to loss of shallow- } \\
\text { water plants that are unable to migrate } \\
\text { up the shoreline, or where available } \\
\text { habitat is limited }\end{array}$ & $\begin{array}{l}\downarrow \text { Dispersal opportunities due to increases in the } \\
\text { rate that rafts are consumed or degraded } \\
\downarrow \text { Protection from predators due to lower habitat } \\
\text { complexity and smaller raft sizes } \\
\downarrow \text { Size and diversity of rafting organisms due to } \\
\text { decreases in average raft size and habitat } \\
\text { complexity }\end{array}$ \\
\hline $\begin{array}{l}\downarrow \uparrow \text { TRANSPORT patterns of } \\
\text { rafts }\end{array}$ & $\begin{array}{l}\downarrow \uparrow \text { Circulation patterns due to a } \\
\text { reduction in global temperature differ- } \\
\text { ential and concomitant shifts in pre- } \\
\text { vailing wind patterns, leading to inten- } \\
\text { sification in some regions (e.g. coasts } \\
\text { and seas adjacent to poleward western } \\
\text { boundary currents, such as the eastern } \\
\text { coasts of Australia and the US) and re- } \\
\text { ductions in others (e.g. North Atlantic) }\end{array}$ & $\begin{array}{l}\downarrow \uparrow \text { Dispersal duration depending on how } \\
\text { circulation patterns affect raft trajectories } \\
\text { (e.g. } \downarrow \text { connectivity with slower rates of drift) }\end{array}$ \\
\hline $\begin{array}{l}\downarrow \text { PERSISTENCE of rafts due } \\
\text { to increases in raft degrada- } \\
\text { tion, loss of buoyancy, strand- } \\
\text { ing on shorelines, and replace- } \\
\text { ment of slow-decomposing } \\
\text { species (e.g. kelps) with fast- } \\
\text { decomposing, palatable, } \\
\text { opportunistic algae }\end{array}$ & $\begin{array}{l}\uparrow \text { Wave height causing increased } \\
\text { fragmentation of rafts } \\
\uparrow \text { Intensity of storms leading to } \\
\text { degradation of rafts through scouring, } \\
\text { burial, and reduced light penetration } \\
\uparrow \text { Water temperatures accelerating } \\
\text { microbial breakdown and herbivore } \\
\text { consumption of rafts }\end{array}$ & $\begin{array}{l}\uparrow \text { Potential for organisms to be deposited in } \\
\text { unsuitable habitat if rafts disintegrate or lose } \\
\text { buoyancy before reaching a suitable destination } \\
\downarrow \uparrow \text { Dispersal duration (with concomitant } \\
\text { implication for species ranges) depending on } \\
\text { whether rafts are pushed onshore or offshore } \\
\downarrow \text { Dispersal duration due to production of less } \\
\text { buoyant and faster-degrading rafts }\end{array}$ \\
\hline
\end{tabular}

1995). Furthermore, urchin grazing can cause detachment of large amounts of seagrass (Klumpp et al. 1993). Metabolic theory predicts that with warming, the metabolic rates of herbivores will increase (Brown et al. 2004). This will enhance rates of herbivore foraging and growth, increasing top-down effects. To some degree, this could be counteracted by macrophyte defenses against herbivores (e.g. secondary metabolites; Macaya et al. 2005), but this will incur costs to macrophytes.

Less well understood is whether the altered hydrodynamic regimes predicted under climate change will enhance dislodgement of macrophytic material from the benthos. Climate change is predicted to enhance the intensity of storms in many areas, but decrease their frequency (IPCC 2007). Storms increase drag forces on plants, greatly enhancing break- age of stipes and detachment of holdfasts (Duggins et al. 2003), particularly where these have already been weakened by other processes such as herbivory (Tegner et al. 1995). Where climate change leads to irregular, extreme events, it might be expected that macrophytes will not be adapted to withstand wave forces, and high rates of dislodgement may occur (Table 1). Morphological adaptations to wave exposure, such as enhanced stipe flexibility, increased stipe diameter, and decreased spinousity that reduce drag and increase strength (Koehl 1986, Duggins et al. 2003, Wernberg \& Vanderklift 2010), generally require press disturbance to be induced.

Global climate change not only has the capacity to modify the supply of raft material by influencing rates of detachment, but also by altering the distribution and productivity of source populations of macro- 
phytes. Most macrophytes display thermally defined growth optima and have distributions that are determined by their tolerance to high summer maxima and low winter minima (Short \& Neckles 1999, Adey \& Steneck 2001). In particular, kelps, which are among the most important sources of floating material and which dominate cold-water coastal zones, become physiologically stressed at high sea temperatures (Tegner et al. 1996, Gerard 1997). Under climate warming, cold-water species are predicted to shift poleward and eventually contract in range, whereas warm-water species are predicted to increase in abundance and expand their distributions (Helmuth et al. 2006, Sorte et al. 2010). In coastal environments, where seagrass may contribute to shorterdistance dispersal of rafting organisms, warming coupled with anthropogenic nutrient loading is predicted to reduce the availability of macrophytic material for rafting by favoring growth of epiphytic algae over seagrasses and shrinking seagrass distributions (e.g. Micheli et al. 2008, Russell et al. 2009). Away from the influences of urban settlements, kelps may experience enhanced productivity as a consequence of an elevated $\mathrm{CO}_{2}$ environment (Hepburn et al. 2011). Where hitchhikers do not display similar distributional changes as their macrophytic rafts, an uncoupling between supply and hitchhiking may result.

\section{RAFT QUALITY}

Aquatic macrophytes vary in their quality as rafts, in terms of both their food value and ability to transport organisms. High-quality rafts can support dense and diverse communities of invertebrates over sustained periods of time, offering them a source of nutrition and protection from predators. In contrast, lower-quality rafts support few individuals of few taxa, for only short periods of time. Shifts in the community composition of algal assemblages as a consequence of interacting effects of climate change and other stressors will influence the size, buoyancy, and palatability of rafts. In particular, in coastal regions, where the combined effects of warming and nutrient enrichment lead to a shift from kelps to ephemeral species (e.g. Connell \& Russell 2010), large impacts on raft quality may result.

In comparison to the rafts produced by kelp and fucoid algae, rafts produced by fast-growing red and green algae are typically small in size. Diminishing the raft size reduces the number and the maximum body size of fauna that can be supported before the raft starts to sink (Thiel \& Gutow 2005b). Furthermore, decreasing raft sizes might be expected to reduce the number of microhabitats available to hitchhikers. Consequently, larger rafts typically support greater abundances and diversities of fauna (Thiel \& Gutow 2005b). The prediction, therefore, is that where the interacting effects of coastal development and climate change lead to shifts from large macroalgae to ephemeral and turfing species, the rafts thereby produced will support fewer species, of fewer taxa.

Additionally, where kelps are replaced with turfing species (Connell \& Russell 2010), raft formation is likely to be restricted to narrow windows of time that do not necessarily correspond to the timing of recruitment events of rafting fauna. Due to their gasfilled pneumatocysts, many species of brown algae maintain positive buoyancy throughout the year. By contrast, most red and green algae are only buoyant when gas bubbles get trapped between or within the algal thallus (Dromgoole 1982, Back et al. 2000). This may only occur in the daytime, when the alga is photosynthesizing (Dromgoole 1982), in spring and summer months when photosynthesis is greatest (Back et al. 2000, Gagnon et al. 2011), or when nutrient availability is high (Richardson \& Cullen 1995). Where a mismatch occurs between the timing of plant buoyancy and recruitment events of hitchhikers, the capacity for broad-scale dispersal of organisms may be severely reduced.

Even where buoyant, rafts of ephemeral macroalgae may be short-lived as a result of rapid consumption by grazers and rapid rates of microbial breakdown. Brown algae and seagrasses are often heavily defended with secondary metabolites that deter grazers (e.g. Hay \& Steinberg 1992) which, in some instances, continue to be produced following detachment of the macrophyte from its primary substratum (Rothäusler \& Thiel 2006). Ephemeral algae, by contrast, frequently trade investment in such defenses in favor of high rates of growth and large reproductive output, rendering them more susceptible to consumers (Valentine et al. 2004). Although palatable rafts may provide a food resource for consumers, the trade-off is decreased raft persistence (Rothäusler et al. 2009; Table 1). Where herbivores rapidly consume algal rafts, they, and any other organisms associated with rafts (e.g. suspension feeders), may then be left in open water without suitable habitat.

In areas where climatic change does not lead to shifts in the species of macrophytes contributing to rafts, changes in the quality of constituent species may still occur. Many macrophytes display a high degree of phenotypic plasticity with respect to factors such as light, temperature, water motion, and even 
$\mathrm{CO}_{2}$ and $\mathrm{O}_{2}$ concentrations (Johnson \& Koehl 1994, Kawamata 2001). Where global climate change leads to enhanced storminess and increasingly large seas, macrophytes may respond through changes in size, morphology, and tissue mechanics, each of which will influence raft quality for hitchhikers.

\section{RAFT TRANSPORT}

Floating materials are transported by wind, waves, and ocean currents (Thiel \& Gutow 2005a). Across large spatio-temporal scales, the velocities (Pickard \& Emery 1990) and trajectories (Bushing 1994, Hobday 2000) of rafting material frequently match those of major ocean currents. At smaller scales, wind speeds and directions are important in determining dispersal patterns (see Thiel \& Gutow 2005a). Latitudinal shifts in the strength and extent of major nearshore boundary currents, such as the Gulf Stream or East Australian Current, are expected under most climate change scenarios (Ridgway 2007). Already, anthropogenic forcing has contributed to changes in wind patterns and poleward movement of extratropical storm tracks in both hemispheres (IPCC 2007). How changes in the trajectories and rates of raft transport affect organisms exhibiting rafting behavior as a key part of their life history will depend upon the tolerance of these rafters to the changed dispersal conditions.

Raft trajectories influence the biogeography of rafts and rafting organisms by affecting connectivity among populations (e.g. Thiel \& Haye 2006, Fraser et al. 2009, 2010, 2011, Nikula et al. 2010). Therefore, changes to hydrodynamic processes under climate change will affect connectivity by influencing dispersal opportunities. The overall outcome could be considered positive or negative depending on the identity of the raft or rafting species. For example, changes in patterns of raft transport that lead to increased connectivity might be considered a positive outcome for threatened species, but a negative outcome if it increases the spread of marine pests. Indeed, invasive and introduced species are known to associate with rafts (Minchinton 2006), and there is some evidence to suggest that changes in climate have facilitated invasions by altering raft transport (Martinez et al. 2007). The reversal and strengthening of currents during an El Niño-Southern Oscillation event produced an alternative transport pathway that facilitated the invasion of the Tuamotu archipelago (French Polynesia) by the brown alga Turbinaria ornata (Martinez et al. 2007).

\section{RAFT PERSISTENCE}

The life of a raft typically ends as a result of 1 of 3 processes: raft destruction, loss of buoyancy, or stranding on a shoreline (Thiel \& Gutow 2005a; Fig. 1). Climate change is predicted to decrease raft longevity by acting on each of these processes (Table 1).

First, climate change will influence rates of raft destruction by altering wave and wind climate. The persistence of floating material is inversely related to water and wind motion; increases in either of these forces tend to lead to fragmentation of raft aggregations (Marmorino et al. 2011). Climate models predict significant increases in wave height and wind speed in some regions (e.g. North Atlantic, Wang et al. 2004; North Sea, Grabemann \& Weisse 2008), although this pattern will not be universal (IPCC 2007). Under such conditions, a decreased life expectancy of rafts may be anticipated.

Second, increasing temperatures are likely to accelerate raft decay by influencing the interaction strength between herbivores and primary producers (Rothäusler et al. 2009, 2011b), and by increasing the rate of decay of rafting materials (Rothäusler et al. 2011a). Metabolic theory predicts that as the temperature of an organism approaches its thermal optimum, metabolic rate will increase (Brown et al. 2004). For algaeinvertebrate systems, herbivore vital rates scale more rapidly than algal growth rates with warming, resulting in a net effect of enhancement of top-down control (O'Connor et al. 2009). Field and laboratory observations confirm that warming of the magnitude predicted by climate models (e.g. IPCC 2007) will in many instances produce a net loss of macrophytic material in rafts (Hobday 2000, Gutow 2003, Vandendriessche et al. 2007a), despite the potential for physiological acclimation and compensatory growth by plants in response to smaller increases in temperature (Rothäusler et al. 2011c) and herbivore pressure (Cerda et al. 2009). Effects of grazers will be particularly severe where they destroy structures, such as pneumatocysts, that are critical in maintaining buoyancy (Thiel \& Gutow 2005a). Similarly, damage to plant reproductive structures (e.g. sporophylls in Macrocystis kelps) will limit the overall dispersal potential and potential for establishment of new populations (Rothäusler et al. 2011a,d).

Third, changes in circulation patterns and prevailing wind directions are also likely to result in large changes in raft persistence under future climate scenarios. Changes in circulation patterns are difficult to predict and remain uncertain (IPCC 2007). Nevertheless, in some parts of the world, a shift in winds from 
on- to offshore is likely to decrease raft longevity and the likelihood that rafts will intersect shorelines, while in others, a shift in winds from off- to onshore will potentially increase raft longevity. In the case of coastal organisms advected alongshore via plant rafts, a mechanism must exist to bring the raft and its passengers inshore, away from the prevailing currents, in order for recruitment to occur. At broader (oceanic) scales, slowing of the thermohaline circulation as a result of global warming (IPCC 2007) could slow the rate of transport of rafts, which could limit dispersal opportunities to those organisms that are not able to withstand long transport durations.

\section{CONCLUSIONS AND RESEARCH PRIORITIES}

In summary, we predict that climate change will lead to an enhanced supply of increasingly smaller and short-lived macrophytic rafts, which due to their rapid degradation times would be dispersed only short distances (Table 1). The size of these rafts will preclude transport of larger organisms, and they will support an overall lower diversity of species than at present (Table 1). Simultaneously, climate change will act on the biology of hitchhiking species, potentially accelerating development and reducing the duration of early life history stages, which are particularly critical for the dispersal of sessile invertebrate species (O'Connor et al. 2007, Cowan \& Sponaugle 2009). Climate impacts on hitchhikers will reinforce the trend to reduced dispersal distances and hence lower connectivity.

Given the potential for climate change to have large impacts on dispersal processes such as rafting, it should be included in models predicting changes in species distributions under future scenarios. Otherwise, models may underestimate climate impacts, leading to inappropriate adaptation strategies for conserving biodiversity. Transforming the conceptual model presented in Fig. 1 to a fully quantitative and predictive model will require further experimentation to elucidate climate effects on key biological interactions and ongoing ocean monitoring to better resolve factors influencing transport and dispersal processes. Recent studies have made good progress in advancing our understanding of how abiotic (e.g. temperature, salinity, light) and biotic (e.g. grazing) factors influence raft longevity (e.g. Vandendriessche et al. 2007b, Rothäusler et al. 2009, 2011a,b). Nevertheless, with most studies on this topic coming from a few prolific researchers, conclusions are for the most part confined to a small number of raft identities (e.g.
Macrocystis spp.) and are geographically limited. Studies extending process-level understanding to other types of raft (representing the different classes of macrophytic rafts) and broader geographical ranges (to encompass a wider range of flow conditions) are needed. Further studies should consider the interactive effects of biotic and abiotic factors on the buoyancy and persistence of rafts, with the view that macrophytic materials are dynamic in terms of their ability to respond to stress. Multidisciplinary studies, combining use of tags, GPS surface drifters, and genetic analyses are needed to better understand how long-range dispersal influences distributions (e.g. Muhlin et al. 2008).

Nationally coordinated ocean monitoring programs (e.g. the Australian Integrated Marine Observing System IMOS, http://imos.org.au/about.html) should be utilized to collect region-specific information on organisms that use rafts as a vector for dispersal, as well as the identity of key raft materials. For instance, autonomous underwater ocean gliders are proving to be a relatively cost-effective method for collecting large amounts of data on ocean conditions. Furthermore, shorter-term climate shifts, such as those caused by the El Niño-Southern Oscillation and the Pacific Decadal Oscillation, could be used as case studies to better understand how dispersal processes respond to climatic change. Only with a complete understanding of the underlying processes will we be able to incorporate dispersal into models for predicting outcomes of climatic change and adaptive management scenarios.

Acknowledgements. We thank Associate Editor L. Benedetti-Cecchi, M. Thiel, and 2 anonymous reviewers for providing many constructive suggestions that improved the manuscript. Funding was provided by a Brian Robinson Fellowship (P.M.), a Paddy Pallin Foundation Human Society International Science Grant (P.M.), and an American Australian Association Dow Chemical Company Fellowship (P.M.).

\section{LITERATURE CITED}

Adey WH, Steneck RS (2001) Thermogeography over time creates biogeographic regions: a temperature/space/ time-integrated model and an abundance-weighted test for benthic marine algae. J Phycol 37:677-698

$>$ Ang POJ (1985) Regeneration studies of Sargassum siliquosum J. ag. and S. paniculatum J. Ag. (Phaeophyta, Sargassaceae). Bot Mar 28:231-235

Back S, Lehvo A, Blomster J (2000) Mass occurrence of unattached Enteromorpha intestinalis on the Finnish Baltic Sea coast. Ann Bot Fenn 37:155-161

Brown JH, Gillooly JF, Allen AP, Savage VM, West GB (2004) Toward a metabolic theory of ecology. Ecology 85: 1771-1789 
Bushing WW (1994) Biogeographic and ecological implications of kelp rafting as a dispersal vector for marine invertebrates. In: Halvorson WL, Maender GJ (eds) California Islands Symposium: update on the status of resources. Santa Barbara Museum of Natural History, Santa Barbara, CA, p 103-110

> Cerda O, Karsten U, Rothäusler E, Tala F, Thiel M (2009) Compensatory growth of the kelp Macrocystis integrifolia (Phaeophyceae, Laminariales) against grazing of Peramphithoe femorata (Amphipoda, Ampithoidae) in northern-central Chile. J Exp Mar Biol Ecol 377:61-67

Connell SD, Russell BD (2010) The direct effects of increasing $\mathrm{CO}_{2}$ and temperature on non-calcifying organisms: increasing the potential for phase shifts in kelp forests. Proc R Soc Lond B Biol Sci 277:1409-1415

Cowen RK, Sponaugle S (2009) Larval dispersal and marine population connectivity. Annu Rev Mar Sci 1:443-466

> Dempster T, Kingsford MJ (2004) Drifting objects as habitat for pelagic juvenile fish off New South Wales, Australia. Mar Freshw Res 55:675-687

> Dromgoole FI (1982) The buoyant properties of Codium. Bot Mar 25:391-397

> Duggins DO, Eckman JE, Siddon CE, Klinger T (2003) Population, morphometric and biomechanical studies of three understory kelps along a hydrodynamic gradient. Mar Ecol Prog Ser 265:57-76

Fraser CI, Nikula R, Spencer HG, Waters JM (2009) Kelp genes reveal effects of subantarctic sea ice during the Last Glacial Maximum. Proc Natl Acad Sci USA 106: 3249-3253

Fraser CI, Thiel M, Spencer HG, Waters JM (2010) Contemporary habitat discontinuity and historic glacial ice drive genetic divergence in Chilean kelp. BMC Evol Biol 10:10

> Fraser CI, Nikula R, Waters JM (2011) Oceanic rafting by a coastal community. Proc R Soc Lond B Biol Sci 278: 649-655

Gagnon K, McKindsey CW, Johnson LE (2011) Dispersal potential of invasive algae: the determinants of buoyancy in Codium fragile ssp. fragile. Mar Biol 158:2449-2458

- Gerard VA (1997) The role of nitrogen nutrition in hightemperature tolerance of the kelp, Laminaria saccharina (Chromophyta). J Phycol 33:800-810

> Gillespie RG, Baldwin BG, Waters JM, Fraser CI, Nikula R, Roderick GK (in press) Long-distance dispersal: a framework for hypothesis testing. Trends Ecol Evol

Grabemann I, Weisse R (2008) Climate change impact on extreme wave conditions in the North Sea: an ensemble study. Ocean Dyn 58:199-212

> Gutow L (2003) Local population persistence as a precondition for large-scale dispersal of Idotea metallica (Crustacea, Isopoda) on drifting habitat patches. Hydrobiologia 503:45-48

Hay ME, Steinberg PD (1992) The chemical ecology of plant-herbivore interactions in marine versus terrestrial communities. In: Rosenthal GA, Berenbaum MR (eds) Herbivores: their interaction with secondary metabolites, Vol 2. Evolutionary and ecological processes. Academic Press, San Diego, CA, p 371-413

> Helmuth B, Mieszkowska N, Moore P, Hawkins SJ (2006) Living on the edge of two changing worlds: forecasting the responses of rocky intertidal ecosystems to climate change. Annu Rev Ecol Evol Syst 37:373-404

> Hepburn CD, Pritchard DW, Cornwall CE, McLeod RJ, Beardall J, Raven JA, Hurd CL (2011) Diversity of carbon use strategies in a kelp forest community: implications for a high $\mathrm{CO}_{2}$ ocean. Glob Change Biol 17:2488-2497

Hinojosa IA, Rivadeneira MM, Thiel M (2011) Temporal and spatial distribution of floating objects in coastal waters of central-southern Chile and Patagonian fjords. Cont Shelf Res 31:172-186

- Hobday AJ (2000) Abundance and dispersal of drifting kelp Macrocystis pyrifera rafts in the Southern California Bight. Mar Ecol Prog Ser 195:101-116

Hosokawa S, Nakamura Y, Kuwae T (2009) Increasing temperature induces shorter leaf life span in an aquatic plant. Oikos 118:1158-1163

Huntley B, Green RE, Collingham YC, Hill JK and others (2004) The performance of models relating species geographical distributions to climate is independent of trophic level. Ecol Lett 7:417-426

> Ingólfsson A (2000) Colonization of floating seaweed by pelagic and subtidal benthic animals in southwestern Iceland. Hydrobiologia 440:181-189

IPCC (Intergovernmental Panel on Climate Change) (2007) Climate change 2007: the physical science basis. IPCC, Cambridge and New York, NY

> Johnson AS, Koehl MAR (1994) Maintenance of dynamic strain similarity and environmental stress factor in different flow habitats: thallus allometry and material properties of a giant kelp. J Exp Biol 195:381-410

Kawamata S (2001) Adaptive mechanical tolerance and dislodgement velocity of the kelp Laminaria japonica in wave-induced water motion. Mar Ecol Prog Ser 211: 89-104

Kerr EA, Strother S (1990) Seasonal changes in standing crop of Zostera muelleri in south-eastern Australia. Aquat Bot 38:369-376

Kingsford MJ (1992) Drift algae and small fish in coastal waters of northeastern New Zealand. Mar Ecol Prog Ser 80:41-55

Klumpp DW, Salita-Espinosa JT, Fortes MD (1993) Feeding ecology and trophic role of sea urchins in a tropical seagrass community. Aquat Bot 45:205-229

Koehl MAR (1986) Seaweeds in moving water: form and mechanical function. In: Givnish TJ (ed) On the economy of plant form and function. Cambridge University Press, Cambridge, p 603-634

Lüning K (1990) Seaweeds: their environment, biogeography, and ecophysiology. Wiley Interscience, New York, NY

Macaya EC, Rothäusler E, Thiel M, Molis M, Wahl M (2005) Induction of defenses and within-alga variation of palatability in two brown algae from the northerncentral coast of Chile: effects of mesograzers and UV radiation. J Exp Mar Biol Ecol 325:214-227

Maestre FT, Bowker MA, Escolar C, Puche MD and others (2010) Do biotic interactions modulate ecosystem functioning along stress gradients? Insights from semi-arid plant and biological soil crust communities. Philos Trans R Soc B Biol Sci 365:2057-2070

Marmorino GO, Miller WD, Smith GB, Bowles JH (2011) Airborne imagery of a disintegrating Sargassum drift line. Deep-Sea Res I 58:316-321

- Martinez E, Maamaatuaiahutapu K, Payri C, Ganachaud A (2007) Turbinaria ornata invasion in the Tuamotu Archipelago, French Polynesia: ocean drift connectivity. Coral Reefs 26:79-86

Matesanz S, Escudero A, Valladares F (2009) Impact of three global change drivers on a Mediterranean shrub. Ecology 90:2609-2621

Menge BA, Chan F, Nielsen KJ, Di Lorenzo E, Lubchenco J (2009) Climatic variation alters supply-side ecology: impact of climate patterns on phytoplankton and mussel recruitment. Ecol Monogr 79:379-395

Micheli F, Bishop MJ, Peterson CH, Rivera J (2008) Alter- 
ation of seagrass species composition and function over two decades. Ecol Monogr 78:225-244

Minchinton TE (2006) Rafting on wrack as a mode of dispersal for plants in coastal marshes. Aquat Bot 84:372-376

> Muhlin JF, Engel CR, Stessel R, Weatherbee RA, Brawley SH (2008) The influence of coastal topography, circulation patterns, and rafting in structuring populations of an intertidal alga. Mol Ecol 17:1198-1210

> Nathan R, Muller-Landau HC (2000) Spatial patterns of seed dispersal, their determinants and consequences for recruitment. Trends Ecol Evol 15:278-285

Nikula R, Fraser CI, Spencer HG, Waters JM (2010) Circumpolar dispersal by rafting in two subantarctic kelpdwelling crustaceans. Mar Ecol Prog Ser 405:221-230

O'Connor MI, Bruno JF, Gaines SD, Halpern BS, Lester SE, Kinlan BP, Weiss JM (2007) Temperature control of larval dispersal and the implications for marine ecology, evolution, and conservation. Proc Natl Acad Sci USA 104: 1266-1271

O'Connor MI, Piehler MF, Leech DM, Anton A, Bruno JF (2009) Warming and resource availability shift food web structure and metabolism. PLoS Biol 7:e1000178

> Ohta I, Tachihara K (2004) Larval development and food habits of the marbled parrotfish, Leptoscarus vaigiensis, associated with drifting algae. Ichthyol Res 51:63-69

Pickard GI, Emery WJ (1990) Descriptive physical oceanography, Vol 5. Butterworth-Heinemann, Oxford

Richardson TL, Cullen JJ (1995) Changes in buoyancy and chemical composition during growth of a coastal marine diatom: ecological and biogeochemical consequences. Mar Ecol Prog Ser 128:77-90

Ridgway KR (2007) Long-term trend and decadal variability of the southward penetration of the East Australian Current. Geophys Res Lett 34:L13613

Rothäusler E, Thiel M (2006) Effect of detachment on the palatability of two kelp species. J Appl Phycol 18:423-435

Rothäusler E, Gomez I, Hinojosa IA, Karsten U, Tala F, Thiel M (2009) Effect of temperature and grazing on growth and reproduction of floating Macrocystis spp. (Phaeophyceae) along a latitudinal gradient. J Phycol 45:547-559

Rothäusler E, Gomez I, Hinojosa IA, Karsten U, Miranda L, Tala F, Thiel M (2011a) Kelp rafts in the Humboldt Current: interplay of abiotic and biotic factors limit their floating persistence and dispersal potential. Limnol Oceanogr 56:1751-1763

Rothäusler E, Gomez I, Hinojosa IA, Karsten U, Tala F, Thiel M (2011b) Physiological performance of floating giant kelp Macrocystis pyrifera (Phaeophyceae): latitudinal variability in the effects of temperature and grazing. J Phycol 47:269-281

Rothäusler E, Gomez I, Karsten U, Tala F, Thiel M (2011c) Physiological acclimation of floating Macrocystis pyrifera to temperature and irradiance ensures long-term persistence at the sea surface at mid-latitudes. J Exp Mar Biol Ecol 405:33-41

Rothäusler E, Gomez I, Karsten U, Tala F, Thiel M (2011d) UV-radiation versus grazing pressure: long-term floating of kelp rafts (Macrocystis pyrifera) is facilitated by efficient photoacclimation but undermined by grazing losses. Mar Biol 158:127-141

Russell BD, Thompson JAI, Falkenberg LJ, Connell SD (2009) Synergistic effects of climate change and local stressors: $\mathrm{CO}_{2}$ and nutrient-driven change in subtidal rocky habitats. Glob Change Biol 15:2153-2162

Editorial responsibility: Lisandro Benedetti-Cecchi, Pisa, Italy
Schweiger O, Biesmeijer JC, Bommarco R, Hickler T and others (2010) Multiple stressors on biotic interactions: how climate change and alien species interact to affect pollination. Biol Rev Camb Philos Soc 85:777-795

Short FT, Neckles HA (1999) The effects of global climate change on seagrasses. Aquat Bot 63:169-196

> Sorte CJB, Williams SL, Carlton JT (2010) Marine range shifts and species introductions: comparative spread rates and community impacts. Glob Ecol Biogeogr 19:303-316

Sousa WP, Kennedy PG, Mitchell BJ, Ordonez BM (2007) Supply-side ecology in mangroves: Do propagule dispersal and seedling establishment explain forest structure? Ecol Monogr 77:53-76

- Tegner MJ, Dayton PK, Edwards PB, Riser KL (1995) Sea urchin cavitation of giant kelp (Macrocystis pyrifera Agardh, C.) holdfasts and its effects on kelp mortality across a large California forest. J Exp Mar Biol Ecol 191: 83-99

Tegner MJ, Dayton PK, Edwards PB, Riser KL (1996) Is there evidence for long-term climatic change in southern California kelp forests? Calif Coop Ocean Fish Invest Rep 37 : 111-126

Thiel M (2003) Rafting of benthic macrofauna: important factors determining the temporal succession of the assemblage on detached macroalgae. Hydrobiologia 503:49-57

Thiel M, Gutow L (2005a) The ecology of rafting in the marine environment. I. The floating substrata. Oceanogr Mar Biol Annu Rev 42:181-263

> Thiel M, Gutow L (2005b) The ecology of rafting in the marine environment. II. The rafting organisms and community. Oceanogr Mar Biol Annu Rev 43:279-418

Thiel M, Haye PA (2006) The ecology of rafting in the marine environment. III. Biogeographical and evolutionary consequences. Oceanogr Mar Biol Annu Rev 44:323-429

Thiel M, Hinojosa IA, Joschko T, Gutow L (2011) Spatiotemporal distribution of floating objects in the German Bight (North Sea). J Sea Res 65:368-379

> Thuiller W, Lavorel S, Araujo MB (2005) Niche properties and geographical extent as predictors of species sensitivity to climate change. Glob Ecol Biogeogr 14:347-357

- Valentine JF, Blythe EF, Madhavan S, Sherman TD (2004) Effects of simulated herbivory on nitrogen enzyme levels, assimilation and allocation in Thalassia testudinum. Aquat Bot 79:235-255

> Vandendriessche S, Messiaen M, O'Flynn S, Vincx M, Degraer S (2007a) Hiding and feeding in floating seaweed: floating seaweed clumps as possible refuges or feeding grounds for fishes. Estuar Coast Shelf Sci 71:691-703

> Vandendriessche S, Vincx M, Degraer S (2007b) Floating seaweed and the influences of temperature, grazing and clump size on raft longevity - a microcosm study. J Exp Mar Biol Ecol 343:64-73

- Wang XLL, Zwiers FW, Swail VR (2004) North Atlantic Ocean wave climate change scenarios for the twentyfirst century. J Clim 17:2368-2383

> Warren MS, Hill JK, Thomas JA, Asher J and others (2001) Rapid responses of British butterflies to opposing forces of climate and habitat change. Nature 414:65-69

> Wernberg T, Vanderklift MA (2010) Contribution of temporal and spatial components to morphological variation in the kelp Ecklonia (Laminariales). J Phycol 46:153-161

Wetzel RL, Penhale PA (1983) Production ecology of seagrass communities in lower Chesapeake Bay. Mar Technol Soc J 17:22-31

Submitted: June 15, 2011; Accepted: November 23, 2011 Proofs received from author(s): December 6, 2011 